\title{
Haemophagocytic lymphohistiocytosis with pulmonary mucormycosis: fatal association
}

\author{
Deepanjan Bhattacharya, ${ }^{1}$ Rajalakshmi lyer, ${ }^{1}$ Karthi Nallasamy, ${ }^{1}$ Kim Vaiphei ${ }^{2}$
}

'Pediatrics, Post Graduate Institute of Medical Education and Research, Chandigarh, India ${ }^{2}$ Histopathology, Post Graduate Institute of Medical Education and Research, Chandigarh, India

\section{Correspondence to} Dr Deepanjan Bhattacharya, b.deepanjan@yahoo.co.in

Accepted 15 May 2019
Check for updates

(c) BMJ Publishing Group Limited 2019. No commercial re-use. See rights and permissions. Published by BMJ.

To cite: Bhattacharya $\mathrm{D}$, lyer R, Nallasamy $K$, et al. BMJ Case Rep 2019:12:e230587. doi:10.1136/bcr-2019230587

\section{DESCRIPTION}

We report a 7-month-old infant, who presented with acute febrile encephalopathy, and was in respiratory failure at admission, for which he was started on invasive ventilation. Systemic examination was unremarkable. Investigations revealed pancytopenia (haemoglobin- $82 \mathrm{~g} / \mathrm{L}$; total leucocyte count $-2.4 \times 10^{9} / \mathrm{L}$; platelet $\left.-49 \times 10^{9} / \mathrm{L}\right)$, coagulopathy (International normalized ratio -2.00, Partial Thromboplastin Time-48 s), transamnitis (aspartate transaminase -708 IU/L, alanine transaminase-1553 IU/L) with normal bilirubin. Procalcitonin was elevated and he was started on doxycycline, ceftriaxone and acyclovir. Neuroimaging was normal. Blood culture was sterile and serologies for scrub typhus, leptospirosis, dengue and hepatitis A-E were negative. Ferritin was elevated and fibrinogen was low. Cerebrospinal fluid (CSF) study showed lymphocytic pleocytosis (80 cells/ $\mu \mathrm{L}, 100 \%$ lymphocytes) with elevated protein $(378 \mathrm{mg} / \mathrm{dL})$ and normal sugar $(110 \mathrm{mg} /$ $\mathrm{dL}$ ) with negative Gram stain and sterile culture. PCR for herpes simplex virus (types 1 and 2) was negative.

He developed progressive multiorgan dysfunction, in the form of acute respiratory distress syndrome, acute kidney injure and shock, to which he succumbed on D3 of hospital stay.

Postmortem biopsies from lung showed alveolar spaces filled with neutrophil-rich infiltrate with broad aseptate hyphae conforming to morphology of mucormycosis(figure 1A), and bone marrow showed increased histiocytes showing florid haemophagocytosis (figure 1B).
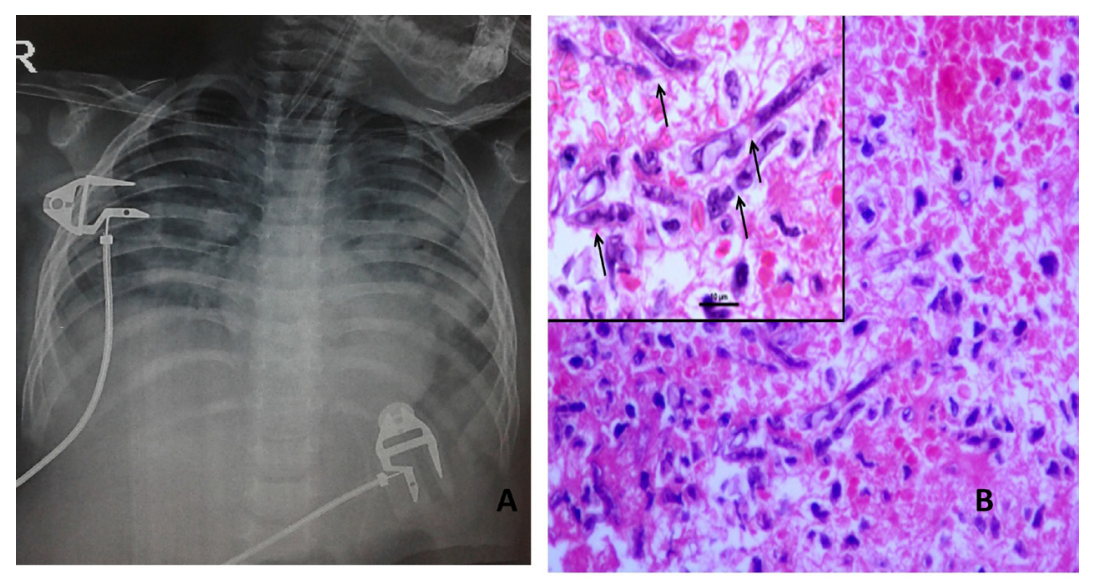

Figure 1 (A) Chest X-ray showing bilateral homogenous fluffy infiltrates. (B) Photomicrograph of the postmortem lung biopsy showing alveoli filled with neutrophil-rich exudates along with many fungal profiles. In the inset photograph, these are seen as well-defined hyphae and irregular-shaped-foldable profiles which are highlighted by the black arrows $(\mathrm{H} \& \mathrm{E}, \times 150$, inset $-\times 500)$.

Our index child had features of multiorgan dysfunction, with pancytopenia, hyperferritinaemia and hypofibrinogenaemia, although the diagnosis of haemophagocytic lymphohistiocytosis (HLH) could only be made postmortem using the HLH 2004 criteria. $^{12}$ Liver dysfunction has been well described in HLH, and usually presents as elevated transaminase levels with jaundice seen in less than half the cases. ${ }^{3}$ Central nervous system is quite often involved with neurological symptoms in as many as $46 \%$, and CSF pleocytosis may occur in $56 \%$ of cases. ${ }^{4}$

Distinguishing HLH from bacterial sepsis is extremely difficult since they may have coexisting features like pancytopenia, coagulopathy and multiorgan dysfunction. Procalcitonin which is used as a marker for sepsis can also be elevated in HLH.

Mucormycosis is the third most common fungal infection in children, with Rhizopus being the most frequently isolated species. Predominant risk factors include haematological malignancy, stem cell or solid organ transplant recipients, diabetes mellitus, iron overload and immunocompromised states. ${ }^{5}$ However, there may not be any evident risk factor as in our index child. ${ }^{6}$

Mucormycosis-associated HLH has rarely been described in literature, and has only been reported in adults.

There have been infrequent reports of mucormyocosis-associated HLH in adults by Inagaki et al, ${ }^{7}$ Rajagopala et $a l^{8}$ and Arena et al. ${ }^{9}$ However, all were associated with $100 \%$ mortality rate, and diagnoses could be established by postmortem biopsies only.

Bhattacharya D, et al. BMJ Case Rep 2019;12:e230587. doi:10.1136/bcr-2019-230587 
Management of HLH is based on aetiology. Primary HLH is treated as per HLH-2004 protocol, which includes vincristine, etoposide, cyclosporine A and dexamethasone. Haematopoietic stem cell transplant is indicated in proven familial or genetic disease, or that which is severe and persistent, or reactivated. In case of infection-triggered HLH, adequate treatment of the triggering infection is necessary. Emapalumab, a monoclonal antibody against interferon $\gamma$, has been recently approved by Food \& Drug Administration (FDA)for primary HLH.

\section{Learning points}

- Haemophagocytic lymphohistiocytosis (HLH) is a strong mimicker of severe sepsis with multiorgan dysfunction.

- Pancytopenia, low fibrinogen and elevated ferritin can help in early identification.

- Mucormycosis-associated HLH is extremely rare and invariably fatal as per literature.

Contributors DB and RI: patient management, literature review and preparation of the initial draft of the manuscript. KN: clinician-in-charge, critical review of the manuscript for important intellectual content and final approval of the version to be published. KV: reviewed histopathology slides, critical review of manuscript.

Funding The authors have not declared a specific grant for this research from any funding agency in the public, commercial or not-for-profit sectors.
Competing interests None declared.

Patient consent for publication Parental/guardian consent obtained.

Provenance and peer review Not commissioned; externally peer reviewed.

\section{REFERENCES}

1 Henter Jl, Horne A, Aricó M, et al. HLH-2004: Diagnostic and therapeutic guidelines for hemophagocytic lymphohistiocytosis. Pediatr Blood Cancer 2007;48:124-31.

2 Ishii E. Hemophagocytic Lymphohistiocytosis in Children: Pathogenesis and Treatment. Front Pediatr 2016;4:47.

3 de Kerguenec $\mathrm{C}$, Hillaire $\mathrm{S}$, Molinié $\mathrm{V}$, et al. Hepatic manifestations of hemophagocytic syndrome: a study of 30 cases. Am J Gastroenterol 2001;96:852-7.

$4 \mathrm{Kim}$ MM, Yum MS, Choi HW, et al. Central nervous system (CNS) involvement is a critical prognostic factor for hemophagocytic lymphohistiocytosis. Korean J Hematol 2012:47:273-80.

5 Francis JR, Villanueva P, Bryant P, et al. Mucormycosis in Children: Review and Recommendations for Management. J Pediatric Infect Dis Soc 2018;7:159-64.

6 Pana ZD, Seidel D, Skiada A, et al. Collaborators of Zygomyco.net and/or FungiScope Registries. Invasive mucormycosis in children: an epidemiologic study in European and non-European countries based on two registries. BMC Infect Dis 2016;16:667.

7 Inagaki N, Sugimoto K, Hosone M, et al. Disseminated Mucor infection and thrombotic microangiopathy in lymphoma-associated hemophagocytic syndrome. Int J Hematol 2008;88:355-6.

8 Rajagopala S, Singh N, Agarwal R, et al. Severe hemophagocytic lymphohistiocytosis in adults-experience from an intensive care unit from North India. Indian J Crit Care Med 2012;16:198-203.

9 Arena V, De-Giorgio F, Pennacchia I, et al. Haemophagocytic syndrome associated with mucormycosis infection. Int J Immunopathol Pharmacol 2012;25:751-5.

Copyright 2019 BMJ Publishing Group. All rights reserved. For permission to reuse any of this content visit

https://www.bmj.com/company/products-services/rights-and-licensing/permissions/

BMJ Case Report Fellows may re-use this article for personal use and teaching without any further permission.

Become a Fellow of BMJ Case Reports today and you can:

- Submit as many cases as you like

- Enjoy fast sympathetic peer review and rapid publication of accepted articles

- Access all the published articles

- Re-use any of the published material for personal use and teaching without further permission

Customer Service

If you have any further queries about your subscription, please contact our customer services team on +44 (0) 2071111105 or via email at support@bmj.com.

Visit casereports.bmj.com for more articles like this and to become a Fellow 